\title{
Japan's HIV blood scandal broadens out
}

Tokyo. The president and two former presidents of Green Cross Corporation (Midori Juji), Japan's leading blood product manufacturer, were arrested last week in connection with the infection of thousands of Japanese with HIV through the use of non-heat-treated blood products in the 1980s.

Further arrests are expected, possibly including a former official of the Ministry of Health and Welfare, as attention in Japan broadens out from a previous focus on haemophiliacs who had been infected with HIV to non-haemophiliacs.

Those arrested last week are the current president of Midori Juji, Takehiko Kawano, and two of his predecessors, Renzo Matsushita and Tadakazu Suyama. They are being held on suspicion of negligence in promoting the continued sale of non-heat-treated blood coagulants in 1986, after safer heat-treated products, including those of the Midori Juji company, were approved for sale by the government in 1985.

The three arrests relate to the death of a non-haemophiliac who was treated with the company's blood coagulants during 1986 for a liver ailment. This has drawn attention to the fact that, as well as haemophiliacs, thousands of nonhaemophiliacs were treated with blood products potentially infected with HIV.

Documents confiscated from the company by prosecutors in Osaka are said to include an internal company memorandum sent in January 1986 to employees by Renzo Matsushita, then president, claiming that the company's non-heattreated products were safer than heattreated ones, as they were made from domestic blood. But in fact nearly all of Midori Juji's blood products were made from blood plasma imported from the United States.

Prosecutors suspect that the three executives continued to promote the sale of nonheat-treated products in 1986, despite knowing the risk of HIV infection and the availability of safer heat-treated products.

According to newspaper and television reports, Midori Juji executives were repeatedly warned of the dangers of HIV contamination of non-heat-treated products by the company's US subsidiary as early as 1984 . But they failed to take any action.

The company was very slow to withdraw non-heat-treated products, leaving them on the market until 1988 - two years after the company had reported to the Ministry of Health and Welfare that withdrawal had been completed (see Nature 380, 472; 1996). As a result, many Japanese may have been infected with HIV several years

after the dangers of non-heat-treated products were realized.

Only this year did it become widely known that thousands of non-haemophiliacs had been treated with the non-heattreated products (see Nature 379, 483; 1996). Despite a belated attempt by the ministry to trace patients treated with the products, most have not been located because hospitals usually destroy patient records after five years, and patients in Japan are seldom told what they are treated with.

Nevertheless, several HIV-infected individuals have been tracked down. Now that haemophiliacs have received large com-pensation settlements from the government and blood-product manufacturers, attention is switching to non-haemophiliac victims of the affair.

Ministry officials face possible criminal charges for failing to order the withdrawal of non-heat-treated products. These may include Akihito Matsumura, who headed the ministry's biologics and antibiotics division from 1984 to 1986.

Last week, the family of the same victim as in the Midori Juji case filed a charge of murder against Matsumura at the Osaka District Prosecutor's office, as they had done earlier this year against Matsushita.

David Swinbanks

\section{UK chief scientist warns of risks of 'Ig Nobel' ridicule}

Boston. The organizers of the annual unofficial 'Ig Nobel' prizes - due to be awarded for the sixth time at Harvard University in Cambridge, Massachusetts, next week - have been warned by Robert May, the British government's chief scientific adviser, that ridiculing genuine scientific projects can be counterproductive.

May expressed his concerns in a recent interview with Nature and in letters sent to Marc Abrahams, editor of the journal Annals of Improbable Research and chief orchestrator of the annual proceedings, and Harvard physicist Sheldon Glashow. He explains his concern on the grounds that last year's award of the Ig Nobel physics prize to scientists at the UK Institute of Food Research in Norwich for "the study of the effects of water content on the compaction behaviour of breakfast cereal flakes" had "caused a lot of grief".

After receiving the award, the scientists were pilloried in the British press and on television. May, who is Royal Society research professor at the University of Oxford, says he is all in favour of lighthearted fun, and acknowledges that research on the "physics of snap, crackle, and pop" does sound humorous. "But it's actually serious work by a serious research group," he says.

In future, May suggests, the directors of the ceremony should secure the permission of prospective recipients, to avoid damaging science in the way that Senator William Proxmire's Golden Fleece awards once did.

The point of the Ig Nobel prizes, he says, should be to strip science of some its selfimportance, and not to hold scientists up to ridicule. "I most earnestly hope that you will revert to attacking those areas that deserve attack, particularly May: awards should in anti-science and attack pseudo-science. pseudo-science, while leaving serious scientists to get on with their work," he asserts.

Abrahams says that he basically agrees with May. "We go to a lot of trouble to contact scientists and get their consent," he says. "The Norwich scientists were willing participants, even to the extent of sending us a funny videotaped acceptance speech."

What happened afterwards, he says, was not anticipated and regrettable. But on balance, he says, the Ig Nobel prize ceremony does more good than harm. "Most of the great breakthroughs in science were once regarded as funny and unimportant. We believe that it's good to pursue ideas that sound funny and see where they lead."

Glashow - the Nobel prizewinning physicist who has participated in several Ig Nobel events - supports Abrahams' view that the ceremony has had a positive effect. "It increases awareness that science can be fun," Glashow says. "Contrary to the stereotype in movies, scientists can enjoy their work and do, in fact, have a sense of humour. At least most of them."

Ten prizes will be awarded at this year's ceremony in Harvard's Sanders Theater. Plaster casts of the feet of actual Nobel laureates will be auctioned, the traditional Heisenberg Uncertainty Lectures will be aired, and the world premiere will take place of Lament del Cockroach, a mini-opera for Nobel laureates and mezzo sopranos.

Steve Nadis 